\title{
Cost effective management of COVID patient transport from treatment centers to their homes: A report related to second wave
}

Fernando GHS, Sridaran S.

\section{Brief introduction on COVID}

On 31st December 2019, the World Health Organization (WHO) Country Office for China was informed about cases of pneumonia of unknown cause in Wuhan, China. Authorities identified a new type of Coronavirus, subsequently named COVID-19 on 30th January 2020 (1). WHO Director-General declared the outbreak of COVID-19 a Public Health Emergency of International Concern (PHEIC), and on 11th March 2020, COVID-19 was characterized as a pandemic (2). The first case of the virus was confirmed in Sri Lanka on 27th January 2020, after a 44-year-old Chinese woman from Hubei Province in China was admitted to the National Institute of Infection Diseases (3). Following that, the first local case was reported on 11th March 2020(4). Since then, the number of COVID cases increased gradually but slowly in the first wave and the spread was rapid in the second wave. According to the recommendation of the COVID-19 expert committee all the COVID-19 positive cases were quarantined at the quarantine centers established by the Ministry of Health.

\section{Discharge criteria and guidelines}

According to the expert opinion and research findings the quarantine period was changed on three occasions. Initially, the positive cases were quarantined for 14 days at the institution and another 14 days at home (5). Then, with the new findings the quarantine period was limited to 14 days at the institution after which they were released to move to the community (6). Now, the expert committee has decided to reduce institutional quarantine period for 10 days followed by 4 days of home quarantine (7).

\section{Treatment centers}

Currently 80 quarantine centers are managed by the Ministry of Health to manage COVID-19 positive cases. They are run by the Ministry staff centrally. These quarantine centers include 47 treatment centers, 26 intermediate treatment centers, two police treatment centers and 4 hotel intermediate treatment centers for health staff (8).

\section{Existing system of transport of patients for home quarantine}

All quarantine centers are coordinated centrally by the Ministry of Health. Positive cases are allocated to relevant quarantine centers by the Ministry and it is the responsibility of the Regional Epidemiologist (RE) to send them to quarantine centers. Sri Lanka Army provided transport facilities to send them to the centers especially in the Western province. Other provinces use their own ambulances and Suwasariya ambulances to send cases to quarantine centers.

However, it is the sole responsibility of the RE to send discharged patients to their resident places. Even though patients are sent from one center they are from different parts of the country and the government had to incur high cost for arranging transport for the discharged patients. Since the existing ambulances are used amidst the normal hospital routine work, discharged patients had to wait more days in the hospital after discharge. Ambulances were sent to far away places to get down even a single patient (Galle to Jaffna, Rathnapura to Jaffna etc.) which cost more than Rs. 20000.00 per journey. Therefore, the existing system incurred a heavy cost to the government and was in efficient.

\section{Adapted method to improve transport system}

A focal point was established at the COVID operation room for management of transport of COVID patients and one Senior Registrar was appointed to handle the discharge of patients in all districts.

Figure 1: Inter-district coordination of discharge of patients

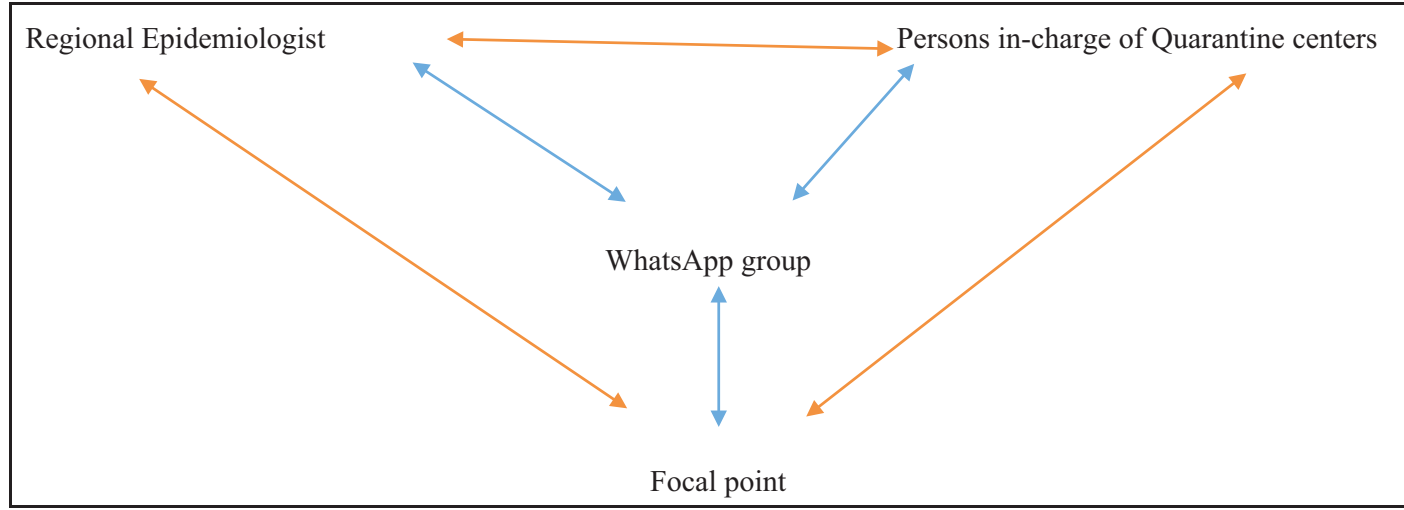


The main objective of the focal point was to use the government vehicles cost effectively and send the patients home on the same day of discharge.

\section{Strategies adapted to develop the transport system}

1. Creation of WhatsApp group connecting all persons in-charge of quarantine centers and the RE (figure1).

2. Allocation of buses of the Nursing Training Schools (NTS) to treatment centers and Ministry disaster unit.

3. Establishment of transit point in the Western province.

The lists of discharged patients from each center were uploaded to WhatsApp group by each treatment center on the previous day. Since most of the patients were from the Western province discharges were also higher in Western province. Few patients in each center were from different districts and they had to be sent to their relevant districts. NTS buses were used to get down patients from peripheral centers to Western province. Some buses collected patients on the way from other centers. All patients were dropped at the transit points established in Maligawatta, Gampaha UC ground and Kalutara and from there sent to their homes using district ambulances. Few ambulances were mobilized from distant districts to the transit points and all patients were dropped on the way at the relevant district. In most of the occasions those ambulances were used for both up and down trips to reduce unit cost. This coordinated transport system reduced sending of ambulances to distant places and it also reduced the movement of many ambulances around the country. Buses were sent every day all around the country according to the demand to take patients from the treatment centers. They were used efficiently and cost effectively every day without rest. One ambulance was allocated to the disaster management unit and was used to transport patients within the Western province during this period enabling transport of all discharges within the same day. During the three months period (16/12/2020 to 16/02/2021), 1547 patients had been transported by that single ambulance. Almost all REs, persons in-charge of quarantine centers and drivers have rendered their fullest support in managing patient transport within the same day even when patients are from faraway places.

\section{Issues related to transport}

- Unavailability of a circular for sending patients by ambulance to their homes. Some heads of the institutions were reluctant to release their ambulance.
- Some heads of institutions did not allow sending their ambulances outside their districts.

- Unavailability of extra ambulances within the district.

\section{Conclusions}

With the help of all the relevant authorities, patients were transported to their homes as early as possible, efficiently and cost effectively.

\section{Recommendations}

- Issuing a special circular regarding release of ambulance for COVID-19 patient transport.

- Allocation of few vehicles to the focal point of the Ministry of Health for COVID-19 purposes.

- Allocation of one bus in each district to transport patients from nearest NTS or government institution.

\section{References}

1. WHO (2021). COVID-19. Retrieved on 16/02/2021. Available at: https://www.who.int/ srilanka/covid-19.

2. WHO (2021). WHO Director-General's opening remarks at the media briefing on COVID-19 - 11 March 2020. Retrieved on 16/02/2021. Available at: https://www.who.int/director-general/speeches/ detail/who-director-general-s-opening-remarks-atthe-media-briefing-on-covid-19---11-march-2020

3. Wikipedia. COVID-19 pandemic in Sri Lanka. Retrieved on 16/02/2021. Available at: https:// en.wikipedia.org/wiki/COVID-19_pandemic_ in_Sri_Lanka\#: : text $=$ The $\% 20$ first $\% 20$ confirmed $\% 20$ case $\% 20$ of, Italy $\% 20$ on $\% 203 \% 20$ March\%202020.

4. Greada World. Sri Lanka: First locally transmitted COVID-19 case March 11 /update 3.Retrived on 16/02/2021. Available at: https://www.garda.com/ crisis24/news-alerts/321466/sri-lanka-first-locallytransmitted-covid-19-case-march-11-update-3.

5. MOH. Updated discharge criteria for COVID 19 patient. Issued on 29/06/2020. By DGHS. Retrieved on 16/02/2021 Available at: https://www.epid. gov.lk/web/images/pdf/Circulars/Corona_virus/ updated $\% 20$ discharge $\% 20$ criteria $\% 20$ for $\% 20$ covid-19\%20patients.pdf. 
6. MOH. Quarantine measures during and after mandatory/ extended quarantine period or after discharge from isolation/intermediate care centers/ hospitals during the pandemic of COVID 19.Issued on 04/12/2020. Retrieved on 16/02/2021. Available at: https://www.epid.gov.lk/web/images/pdf/ Circulars/Corona_virus/scan\%2006-12-2020.pdf

7. MOH. (2020). Discharge criteria for COVID 19 patient( 3rd version).Retrieved on 16/02/2021 Available at: https://www.epid.gov.lk/web/images/ pdf/Circulars/Corona_virus/discharge_citeria_for_ covid_19_patients.pdf.

8. COVID-19 Operation room. Ministry of Heath daily report on 16/02/2021. 